\title{
In vitro influence of amazonian substances on the dental bleaching
}

\author{
Influência in vitro de substâncias amazônicas no clareamento dental \\ Influencia in vitro de sustancias amazónicas en el blanqueamiento dental
}

Received: 02/19/2021 | Reviewed: 02/28/2021 | Accept: 03/02/2021 | Published: 03/09/2021

Celiane Mary Carneiro Tapety

ORCID: https://orcid.org/0000-0002-3235-8942

Universidade Federal do Ceará, Brazil E-mail: cmct@ufc.br

Francisbênia Alves Silvestre

ORCID: https://orcid.org/0000-0001-8620-8678

Faculdade Paulo Picanço, Brazil

E-mail: beniaasilvestre@gmail.com

Mara Natiere Gonçalves Mota

ORCID: https://orcid.org/0000-0002-4838-6948

Faculdade Paulo Picanço, Brazil

E-mail: maranatyere@hotmail.com

Laura Mayrla Candido Vilarouca

ORCID: https://orcid.org/0000-0001-8238-1801 Universidade Federal do Ceará, Brazil

E-mail: lauravilarouca@ hotmail.com

Yvina Karine Parente Carneiro

ORCID: https://orcid.org/0000-0003-4151-8554

Universidade Federal do Ceará, Brazil

E-mail: yvina.karine@yahoo.com.br

Madiana Magalhães Moreira

ORCID: https://orcid.org/0000-0002-2753-0189

Universidade Federal do Ceará, Brazil

E-mail: madimagalhaes@gmail.com

Alessandro Dourado Loguercio

ORCID: https://orcid.org/0000-0001-9880-4856

Universidade Estadual de Ponta Grossa, Brazil

E-mail: aloguercio@hotmail.com

Victor Pinheiro Feitosa

ORCID: https://orcid.org/0000-0001-8795-9967

Faculdade Paulo Picanço, Brazil

E-mail: victor.feitosa@facpp.edu.br

\begin{abstract}
Due to the wide scientific divergence of results among in vitro investigations about the influence of food pigmentation on teeth staining during bleaching, this study aims to evaluate in the laboratory the effectiveness of at-home bleaching using carbamide peroxide (CP), and in-office bleaching using hydrogen peroxide (HP) applied to bovine teeth exposed to açaí and guarana energy drink during the dental whitening process. Extracted bovine incisors were randomly separated into six groups as follows: two control groups (at-home bleaching [HB] and in-office bleaching $[\mathrm{OB}]$ and immersed in artificial saliva), two groups following the immersion in açaí (HBa and $\mathrm{OBa}$ ), and two groups following the immersion in guarana ( $\mathrm{HBg}$ and $\mathrm{OBg}$ ). The immersion cycle was conducted three times a day for five minutes. After the initial reading, the color was registered subsequently to the third (and last) week of whitening process. This procedure was carried out using Easyshade spectrophotometer and Vita shade guide. The data were submitted to a two-way ANOVA test $(\mathrm{p}<0.05)$. The results showed that after three weeks of bleaching, the whitening rate for the OBa group decreased significantly when compared to the other groups, also those submitted to at-home bleaching. After the third week of the whitening process, it was observed that the groups submitted to at-home bleaching presented higher whitening rates than the ones submitted to in-office bleaching. Therefore, the contact with açaí during whitening period may reduce the in-office bleaching efficacy.
\end{abstract}

Keywords: Dental bleaching with açaí; Food pigments; Amazon substances.

\section{Resumo}

Devido à grande divergência de resultados entre estudos in vitro que avaliam a influência de alimentos pigmentantes no manchamento dental durante o clareamento, tal estudo teve como objetivo avaliar em laboratório a efetividade do tratamento clareador caseiro com peróxido de carbamida (PC) 16\% e de consultório com peróxido de hidrogênio (PH) 
$35 \%$ em dentes bovinos submetidos ao contato com açaí e guaraná energético ao decorrer do processo clareador. Incisivos bovinos extraídos foram divididos aleatoriamente em seis grupos: dois grupos controle, submetidos ao clareamento caseiro (CAS) e ao clareamento de consultório (CON) e imersos em saliva artificial, dois grupos imersos em açaí (CASa e CONa), e dois grupos imersos em guaraná (CASg e CONg). O ciclo de imersão foi conduzido três vezes ao dia por cinco minutos. Após a leitura inicial, a cor foi registrada subsequentemente à terceira (e última) semana do processo clareador. Esse procedimento foi realizado usando o espectrofotômetro Easyshade e a escala de cor Vita. Os dados foram submetidos ao teste ANOVA de dois fatores $(\mathrm{p}<0.05)$. Os resultados mostraram que após três semanas de clareamento, a taxa de branqueamento para o grupo CONa reduziram significativamente quando comparado aos outros grupos, também a aqueles submetidos ao clareamento caseiro. Após a terceira semana de processo clareador, foi observado que os grupos submetidos ao clareamento caseiro apresentaram maiores taxas de clareamento que os submetidos ao clareamento de consultório. Então, o contato com açaí durante o período de clareamento pode reduzir a eficácia do clareamento de consultório.

Palavras-chave: Clareamento dental açaí; Pigmentos alimentares; Substâncias da Amazônia.

\section{Resumen}

Debido a la gran divergencia de resultados entre los estudios in vitro que evalúan la influencia de los alimentos pigmentantes en la tinción dental durante el blanqueamiento, este estudio tuvo como objetivo evaluar en el laboratorio la efectividad del tratamiento blanqueador casero con peróxido de carbamida (PC) al $16 \%$ y en consultorio. con peróxido de hidrógeno $(\mathrm{PH})$ al $35 \%$ en dientes de bovino sometidos al contacto con açaí y guaraná energético durante el proceso de blanqueo. Los incisivos bovinos extraídos se dividieron aleatoriamente en seis grupos: dos grupos de control, sometidos a blanqueamiento domiciliario (CAS) y blanqueamiento de oficina (CON) y sumergidos en saliva artificial, dos grupos sumergidos en açaí (CASa y CONa) y dos grupos sumergidos en guaraná. (CASg y CONg). El ciclo de inmersión se realizó tres veces al día durante cinco minutos. Después de la lectura inicial, el color se registró posteriormente a la tercera (y última) semana del proceso de blanqueo. Este procedimiento se realizó utilizando el espectrofotómetro Easyshade y la escala de colores Vita. Los datos se sometieron a la prueba ANOVA bidireccional $(\mathrm{p}<0,05)$. Los resultados mostraron que después de tres semanas de blanqueo, la tasa de blanqueo para el grupo CONa se redujo significativamente en comparación con los otros grupos, también aquellos sometidos a blanqueamiento casero. Después de la tercera semana del proceso de blanqueamiento, se observó que los grupos sometidos a blanqueamiento domiciliario tenían tasas de blanqueo más altas que los sometidos a blanqueamiento de oficina. Por lo tanto, el contacto con açaí durante el período de blanqueamiento puede reducir la efectividad del blanqueamiento en la oficina.

Palabras clave: Blanqueamiento dental con asaí; Pigmentos alimentarios; Sustancias del Amazonas.

\section{Introduction}

Aesthetics has become a major concern among patients, who are dedicated to maintain a smile that is aesthetically harmonious. Samorodnitzki-Naveh et al., (2007) evaluated the satisfaction with aesthetics and found that tooth discoloration was the main reason for dissatisfaction of the population studied. Furthermore, most of the subjects were interested in whitening their teeth.

Tooth color is due to the combination of intrinsic and extrinsic factors. Intrinsic pigmentation is the result of changes in the coloration within the tooth structure before or after eruption; extrinsic factors occur by contact of the teeth with the oral environment and build-up of pigments and dyes from one's diet, after eruption (Sulienman, 2008). We can mention, as some of the foremost pigmenting foodstuffs: coffee, black tea, cola drinks, red wine and açaí, which are often contraindicated during the bleaching treatment, due to the coloration and the acidic pH of these foods (Sulieman, 2008; Mondelli et al., 2012; Costa e Silva et al., 2009; Azer et al., 2010).

Among such pigmenting products, amazonian substances, such as açaí and guarana have been winning over Brazilian consumers. Açaí is a food rich in anthocyanin, a natural dye from the class of flavonoid compounds responsible for its purpleto-black color. Currently, açaí has been in the spotlight, since anthocyanins have become known for their powerful beneficial effects on health, including antimutagenic, anti-inflammatory and antioxidant action. It is also a major source of lipids, proteins, fiber, minerals, and vitamins E and B1 (Ribeiro, 2010).

The aforementioned pigmentations can darken the teeth. In order to return to harmony of color, different techniques are used for whitening vital teeth. Dental whitening is a safe, conservative and effective procedure, usually performed with 
hydrogen peroxide or carbamide peroxide gels at varying concentrations, either through the at-home technique (using teeth whitening trays), or the in-office technique (with or without light activation), or a combination of both types (Bernardon et al., 2010).

However, a diet rich in pigmenting products may impair the bleaching process, since many in vitro studies have related dental bleaching to changes in enamel surface, including increased porosity and surface roughness, as well as reduced microhardness (Mondelli et al., 2015; Pinto et al., 2004). Therefore, it is common for dental practitioners to ask their patients to refrain from consuming dye-rich foods and beverages during bleaching treatment, such as: coffee, black tea, cola drinks, red wine and açaí.

Carlos et al., (2019) correlated tooth staining with such subclinical enamel alterations associated with the consumption of pigmenting dietary components in the period immediately after bleaching. However, after contact with saliva, these values return to normalcy, reinforcing the hypothesis of the remineralizing potential and buffering capacity of saliva (Pinto et al., 2004; Zhao et al., 2019; Berger et al., Rezende et al., 2013). Nonetheless, an adequate period has not yet been established for remineralization to occur after bleaching, thereby reducing the risk of tooth discoloration.

Due to the lack of evidence regarding the effect of contact with Amazonian substances during the bleaching treatment, this study has the aim to evaluate the effectiveness of the at-home whitening treatment with at-home and in-office bleaching in teeth submitted to contact with açaí and guarana energy drink during and after the bleaching process. The hypotheses tested were: 1- Tooth discoloration during at-home and in-office whitening is influenced by frequent contact with açaí. 2- Frequent contact with guarana energy drink interferes with tooth discoloration during at-home and in-office whitening.

\section{Methodology}

\subsection{Materials and Specimen Preparation}

Sixty bovine teeth were kept in $0.1 \%$ Thymol solution until the time of use, when their roots were sectioned just below the cementoenamel junction with the aid of a $0.2-\mathrm{mm}^{2}$ diamond disk (KG Sorensen, Cotia, São Paulo, Brazil). The remaining pulp was excised with endodontic probes and the interior of the chamber was irrigated with saline solution. Then the entrance orifice of the pulp chamber and the cementoenamel junction were completely sealed with acrylic resin, thereby avoiding contact with the pigmenting substances or bleaching materials. The teeth also underwent prophylaxis with pumice and water, and were selected based on their initial coloring (Attin et al., 2003; Mori et al., 2016), which was required to have a value equal to or greater than A3, obtained via a VITA Easyshade spectrophotometer (VITA Zahnfabrik, Bad Säckingen, Germany).

Following preparation, the teeth were immersed in artificial saliva (Molina et al., 2011) and kept in an oven at $37^{\circ} \mathrm{C}$ throughout the experiment, being removed only for placement of the bleaching material and the pigmenting beverages. The artificial saliva was changed every 48 hours.

\subsection{Groups Division}

The teeth were randomly divided into six groups according to the bleaching treatment to which they were submitted and the Amazonian substance in which they were immersed.

Two control groups ( $\mathrm{n}=10)$ immersed in distilled water, one submitted to at-home bleaching (HB; carbamide peroxide 16\%; Whiteness Perfect 10\%, FGM, Joinville, SC, Brazil) and one to in-office bleaching (OB; hydrogen peroxide 35\%; Whiteness HP Blue, FGM, Joinville, SC Brazil), and further four experimental groups ( $\mathrm{n}=10)$. Two of them were submitted to at-home daily bleaching, one immersed in açaí (HBa, Açaí Frooty, Frooty Brasil, São Paulo, Brazil) and the other immersed in 
a commercial guarana energy drink (GuaraMix, Guara Mix Industry, Salvador, Brazil) (HBg), and two other groups submitted to the in-office bleaching, also immersed in açaí $(\mathrm{OBa})$ and guarana energy drink $(\mathrm{OBg})$. The immersion cycles were performed three times daily for five minutes during three weeks.

\subsection{Color readings}

The color readings were performed in the all groups in following the order: baseline (before bleaching) and after the third week of bleaching. Before each reading, the teeth underwent prophylaxis with pumice and water mixture.

The color of the teeth was evaluated using a VITA Easyshade spectrophotometer (VITA Zahnfabrik, Bad Sackingen, Germany), positioned perpendicular to the vestibular surface and in contact therewith, in the middle third of the tooth. The spectrophotometer gives the values of the coordinates $\mathrm{L}^{*}, \mathrm{a}^{*}$ and $\mathrm{b}^{*}$. The $\mathrm{L}^{*}$ axis describes the lightness value and its measure ranges from white to black (from 0 to 100), while the $\mathrm{a}^{*}$ axis measures the hue-chroma in the red-green direction (from +120 to -120$)$, and the $b^{*}$ axis represents the hue-chroma in the blue-yellow direction (+120 to -120$)$.

\subsection{Application of the whitening agent and immersion of teeth}

For applying the whitening agent in the groups submitted to at-home bleaching, acetate trays were prepared for each tooth. The vestibular surface of the plate was filled with carbamide peroxide 16\% (Whiteness Perfect, FGM, Joinville, SC, Brazil) and positioned on the tooth, which remained in contact with the gel for two hours daily for three weeks. At the end of the two-hour session, the bleaching substance was removed with running water and the teeth were stored in artificial saliva at $37^{\circ} \mathrm{C}$. Then, the teeth were immersed in açaí (HBa) or guarana energy drink ( $\mathrm{HBg}$ ) for 5 minutes, three times a day. During 5minute immersion period, they remained at $37^{\circ} \mathrm{C}$ in a laboratory oven.

After the determined period, they were rinsed in running water and stored in artificial saliva until the next immersion or until the next bleaching session. For the groups that underwent in-office bleaching, the application of hydrogen peroxide 35\% (Whiteness HP Blue, FGM, Joinville, SC, Brazil) followed the manufacturer's recommendations, including three sessions with a single application of bleaching agent for 40 minutes in each session, with an interval of seven days between them. After the determined time, the teeth were rinsed in running water and stored in artificial saliva at a temperature of $37^{\circ} \mathrm{C}$ in a laboratory oven. Although they did not undergo daily bleaching, they were also submitted to immersion in açaí (OBa) and guarana energy drink (OBg) every day for 5 minutes, three times a day, at $37^{\circ} \mathrm{C}$ in a laboratory encubator.

\subsection{Experimental design}

In this study, the experimental unit is the tooth, a $2 \times 3$ factorial design was designed (Pereira et al., 2018), with ten replicates for each group $(\mathrm{n}=10)$. The experimental (or independent) variables were: bleaching technique, two levels: at-home bleaching and in-office bleaching; and dyes, three levels: saliva (control), açaí and guarana. The response (or dependent) variable was the $\Delta \mathrm{E}$ between baseline color and the color change after 3 weeks. Also, a second analysis was performed using the color shade unit in baseline and after 3 weeks of bleaching for each bleaching technique (at-home and in-office bleaching). Minitab for Windows software (version 14.12, Minitab Inc., 2004) was used for analyzing the data obtained. Descriptive statistics (mean and standard deviation) and inferential statistics were performed using the two-factor ANOVA parametric test. The level of significance adopted was the conventional value of $5 \%$.

\section{Results}

The $\Delta \mathrm{E}$ data obtained in these experimental conditions established by the bleaching techniques/dyes are presented in 
Table 1. Within the conditions of the study, at-home protocol attained higher $\Delta \mathrm{E}$ than in-office approach $(\mathrm{p}=0.011)$. Overall, guarana immersion was able to obtain higher $\Delta \mathrm{E}$ than control and açaí immersions $(\mathrm{p}=0.009$ and $\mathrm{p}<0.001$ respectively).

Table 1. Means (standard deviations) of $\Delta \mathrm{E}$ after 3 weeks bleaching.

\begin{tabular}{llll}
\hline$\Delta E$ 3 weeks & At-home & In-office & Mean \\
\hline Control & $11.3(3.3)$ & $11.0(2.4)$ & $11.2 \mathrm{~B}$ \\
Açaí & $10.2(4.2)$ & $8.1(1.9)$ & $9.2 \mathrm{~B}$ \\
Guarana & $17.1(3.7)$ & $12.2(3.1)$ & $14.7 \mathrm{~A}$ \\
Mean & $12.9 \mathrm{a}$ & $10.4 \mathrm{~b}$ & \\
\hline
\end{tabular}

*Different uppercase letters in columns and different lowercase letters in row indicate statistical difference ( $\mathrm{p}<0.05)$. Source: Authors.

Further statistical results regarding color scale changing are presented in Tables 2 and 3 separately for each bleaching protocol. In Table 2, it may be observed statistical difference (increase of whitening) with at-home approach even with contact of both pigmenting substances, indicating absence of negative influence on bleaching protocol $(\mathrm{p}=0.168)$. Conversely, data obtained from in-office bleaching protocol and shown in Table 3 demonstrated no statistical change ( $\mathrm{p}=0.839)$ in the color unit after frequent contact with açaí during in-office bleaching, indicating interference of this pigmenting agent on the bleaching effect.

Table 2. Means (standard deviations) of Vita color shades after at-home bleaching.

\begin{tabular}{lll}
\hline Color unit & Baseline & At-home/3 weeks \\
\hline Control & $15.2(0.8)$ & $10.2(1.3)$ \\
Açaí & $15.0(1.7)$ & $11.0(2.4)$ \\
Guarana & $15.2(1.8)$ & $9.0(2.3)$ \\
Mean & $15.1 \mathrm{~A}$ & $10.1 \mathrm{~B}$ \\
\hline
\end{tabular}

*Different letters indicate statistical difference $(\mathrm{p}<0.05)$. Source: Authors.

Table 3. Means (standard deviations) of color scale after in-office bleaching.

\begin{tabular}{lll}
\hline Color unit & Baseline & In-office/3 weeks \\
\hline Control & $15.2(0.8) \mathrm{A}, \mathrm{a}$ & $10.8(2.5) \mathrm{B}, \mathrm{b}$ \\
Açaí & $15.0(1.7) \mathrm{A}, \mathrm{a}$ & $15.2(0.4) \mathrm{A}, \mathrm{a}$ \\
Guarana & $15.6(0.5) \mathrm{A}, \mathrm{a}$ & $11.6(2.2) \mathrm{B}, \mathrm{b}$ \\
\hline
\end{tabular}

*Different uppercase letters in columns and different lowercase letters in lines indicate statistical difference (p <0.05). Source: Authors.

\section{Discussion}

The intense dissemination of the "white smile" as a new standard of beauty in the media has considerably increased patients' interest in tooth bleaching (Rodrigues et al., 2018). This desire for increasingly white teeth leads dentists to strive to 
meet the expectations of their patients, so it is not surprising that tooth discoloration has been the object of study for years.

Therefore, there is a concern by practitioners in performing an effective bleaching treatment. However, laboratory studies have reported changes on the surface of the enamel with bleaching agents, due to their acidic and demineralizing nature, and can thus favor a greater retention of some pigmenting agents in the enamel (Mondelli et al., 2015; Pinto et al., 2004).

Hence, the results of this study confirm the hypothesis that dental staining during in-office bleaching is influenced by frequent contact with açaí, since after third week of treatment followed by immersion in açaí, there are a considerable lower bleaching pattern, as compared to control group. This corroborates the findings of several laboratory studies that verified staining of tooth specimens when submitted to bleaching and immersed in staining solutions such as red wine, black tea, and soft drinks (Carlos et al., 2019; Zhao et al., 2019; Berger et al., 2008).

Nevertheless, this might not occur when using carbamide peroxide during at-home bleaching, thanks to the lower acidity of such agent as well as a milder and slower protocol of whitening when compared to in-office bleaching. Pinto and collaborators (2004) evaluated the microhardness, roughness and surface morphology in enamel after bleaching with carbamide peroxide and hydrogen peroxide at different concentrations and concluded that exposure to hydrogen peroxide used in--office shows a significant increase in the roughness and porosity of the enamel surface compared to the control group, as well as, when compared to different concentrations of carbamide peroxide.

Therefore, it is possible that the artificial saliva, which would play the role of superficial remineralization of the enamel (Nakonieczna-Rudnicka et al., 2015; Liporoni et al., 2010; Caneppele et al., 2009; Cavalli et al., 2019), is not able to reverse such deep and extensive changes as those produced by hydrogen peroxide at high concentrations, as used in the inoffice bleaching technique. This increased porosity of the enamel associated with bleaching occurs mainly due to the temporary mineral loss of calcium and phosphorus associated with protein change in the surface enamel (Briso et al., 2016; Araujo et al., 2011), increasing the permeability as well as the susceptibility to pigmentation, so contact with the dye soon after treatment with the bleaching gel causes the pigments removed by the procedure to be replaced, without effective whitening (Nucci et al., 2004; Spalding et al, 2003).

Nonetheless, at-home bleaching was not influenced by either of the two pigmenting substances in question, as shown in Table 2, thereby rejecting the hypothesis tested in this study. Therefore, at-home bleaching obtained a higher value of $\Delta \mathrm{E}$ than in-office bleaching. This is possibly due to the reduced amount of changes in the surface morphology of the enamel, thus hindering the penetration of pigments, as reported by Nucci (Nucci et al., 2004) after evaluating bleaching treatment with two at-home bleaching agents.

Additionally, the presence and immersion in saliva between the bleaching sessions may have contributed to the remineralization of the enamel surface, reversing small structural changes produced by at-home bleaching substances such as increased porosity and roughness, thus reducing the penetration of pigmenting agents on the surface of the enamel (Mondelli et al., 2015; Pinto et al., 2004).

The remineralizing and buffering role of saliva in prevent the dyes of bleaching teeth was showed by Zhao (2019). In this study, the authors showed significantly higher color changes in teeth that were bleached and immediately exposed to the dye agents, similar to açai. On the other hand, when teeth were bleached, but after that, immersed in saliva for 15 days, there is not significant color change, probably because the effects of the saliva (Zhao et al., 2019).

Another noteworthy factor is the increase of the whitening effect in the groups submitted to daily immersion in guarana, which confirms the hypothesis that this substance influences the dental bleaching process. Regarding the components of the energy drink (natural guarana extract, natural açaí extract and natural ginseng extract), further studies are needed to find 
possible mechanisms that accelerate the bleaching action.

\section{Conclusion}

The color change of in-office bleaching technique was only affected by contact with açaí, but this did not occur with at-home bleaching. On the other hand, the contact with guarana energy drink seems to slightly increase the whitening effect only with at-home bleaching. Future trends should focus on the clinical assessment of açaí consumption during in office bleaching.

\section{Acknowledgements}

This research was supported by Brazilian CAPES grant 23038.006958/2014-96 (PI VPF). Authors have no conflicts of interest regarding any subject of this manuscript.

\section{References}

Attin, T., Manolakis, A., Buchalla, W., \& Hannig, C. (2003). Influence of tea on intrinsic colour of previously bleached enamel. J Oral Rehabil, 30(5), 488494.

Araujo, J., Dobrovolski, M., Kozlowski Junior, V. A., \& Rezende, M. (2021). Use of Plantago major solution for the control of dental biofilm: case report. Research, Society and Development, v. 10, 29610111491-12.

Azer, S.S., Hague, A. L., \& Johnston, W. M. (2010). Effect of pH on tooth discoloration from food colorant in vitro. J Dent, 38(2), 106-109.

Berger, S. B., Coelho, A. S., Oliveira, V. A. P., Cavalli, V., \& Giannini, M. (2008). Enamel susceptibility to red wine staining after 35\% hydrogen peroxide bleaching. J Appl Oral Sci, 16(3), 201-204.

Bernardon, J., Sartori, N., Ballarin, A., Perdigão, J., Lopes, G., \& Baratieri, L. (2010). Clinical performance of vital bleaching techniques. Oper Dent, 35(1), 3 10 .

Briso, A. L., Fagundes, T. C., Gallinari, M. O., Moreira, J., de Almeida, L., Rahal, V., Gonçalves, R. S., \& Santos, P. D. (2016). An in Situ Study of the Influence of Staining Beverages on Color Alteration of Bleached Teeth. Oper Dent, 41(6), 627-633.

Caneppele, T. M. F., Souza, A. C., Valera, M. C., \& Pagani, C. (2009). Influence of tooth soaking in substances with dyes regarding the effectiveness of tooth whitening using 16\% carbamide peroxide. Arq. Odontol, 45(4), 171-177.

Carlos, N. R., Pinto, A., Amaral, F. D., França, F., Turssi, C. P., \& Basting, R. T. (2019). Influence of Staining Solutions on Color Change and Enamel Surface Properties During At-home and In-office Dental Bleaching: An in-Situ Study. Oper Dent, 10.2341/18-236-C.

Cavalli, V., Silva, B. G. D., Berger, S. B., Marson, F. C., Tabchoury, C. P. M., \& Giannini, M. (2019). Decomposition Rate, pH, and Enamel Color Alteration of At-Home and In-Office Bleaching Agents. Braz Dent J, 30(4), 385-396.

Costa e Silva, D., Tiradentes, S. B. S. P., Parente, R. C. P., \& Bandeira, M. F. C. L. (2009). Color change using HSB color system of dental resin composites immersed in different common Amazon region beverages. Acta Amaz, 39(4), 961-968.

Liporoni, P. C., Souto, C. M., Pazinatto, R. B., Cesar, I. C., de Rego, M. A., Mathias, P., \& Cavalli, V. (2010). Enamel susceptibility to coffee and red wine staining at different intervals elapsed from bleaching: a photoreflectance spectrophotometry analysis. Photomed Laser Surg, 28(2), S105-9.

Molina, G. F., Almeida, C. G. R., Guerra, S. C., Cury, J. A., de Almeida, A. P., Barroso, R. C., \& Gerlach, R. F. (2011). Lead deposition in bovine enamel during a $\mathrm{pH}$-cycling regimen simulating the caries process. Caries Res, 45(5),469-74.

Mondelli, R. F. L., Azevedo, J. F. D. G., Francisconi, A. C., Almeida, C. M., \& Ishikiriama, S. K. (2012). Comparative clinical study of the effectiveness of different dental bleaching methods - two-year follow-up. J Appl Oral Sci, 20(4), 435-443.

Mori, A. A., Lima, F. F., Benetti, A. R., Terada, R. S., Fujimaki, M., \& Pascotto, R.C. (2016). Susceptibility to Coffee Staining during Enamel Remineralization Following the In-Office Bleaching Technique: An in-Situ Assessment. J Esthet Restor Dent, 1, S23-31.

Nakonieczna-Rudnicka, M., Bachanek, T., Madejczyki, M., Grajewskai, I., \& Kobyłecka, E. (2015). Teeth whitening versus the influence of extrinsic factors on teeth stains. Przegl Lek, 72(3), 126-30.

Nucci, C., Marchionni, S., Piana, G., Mazzoni, A., \& Prati C. (2004). Morphological evaluation of enamel surface after application of two "home" whitening products. Oral Health Prev Dent, 2(3), 221-229.

Pereira, A. S., Shitsuka, D. M., Parreira, F. J., \& Shitsuka, R. (2018). Metodologia da pesquisa científica. UFSM. https://repositorio.ufsm.br/bitstr eam/handle/1/15824/Lic_Computacao_Metodologia-Pesquisa-Cientifica.pdf?sequence=1. 
Research, Society and Development, v. 10, n. 3, e14010313133, 2021

(CC BY 4.0) | ISSN 2525-3409 | DOI: http://dx.doi.org/10.33448/rsd-v10i3.13133

Pinto, C. F., Oliveira, R., Cavalli, V., \& Giannini, M. (2004). Peroxide bleaching agent effects on enamel surface microhardness, roughness and morphology. Pesqui Odontol Bras, 18(4), 306-311.

Rezende, M., Loguercio, A.D., Reis, A., \& Kossatz, S. (2013). Clinical effects of exposure to coffee during at-home vital bleaching. Oper Dent, 38(6), 229236.

Ribeiro, J.C. (2010). Avaliação do potencial antimutagênico da polpa de açaí (Euterpe oleracea Mart) e do óleo de buriti (Mauritia flexuosa) in vivo. Tese de Doutorado da Faculdade de Ciências Farmacêuticas de Ribeirão Preto, São Paulo.

Rodrigues, J. L., Rocha, P. S., Pardim, S. L. S., Machado, A. C. V., Faria-e-Silva, A. L., \& Seraidarian, P. I. (2018). Association Between In-Office and AtHome Tooth Bleaching: A Single Blind Randomized Clinical Trial. Braz Dent J, 29(2), 133-139.

Samorodnitzki-Naveh, G. R., Geiger, S. B., \& Levin, L. (2007). Patients' satisfaction with dental esthetics. J Am Dent Assoc, 138(6), 805-8.

Spalding, M., Taveira, L. A., \& de Assis, G. F. (2003). Scanning electron microscopy study of dental enamel surface exposed to $35 \%$ hydrogen peroxide: alone, with saliva, and with 10\% carbamide peroxide. Journal of Esthetic and Restorative Dentistry, 15(3), 154-164.

Sulieman, M. A. (2008). An overview of tooth-bleaching techniques: chemistry, safety and efficacy. Periodontol 2000(48), 148-169.

Zhao, X., Zanetti, F., Wang, L., Pan, J., Majeed, S., Malmstrom, H., Peitsch, M. C., Hoeng, J., Ren, Y. (2019). Effects of different discoloration challenges and whitening treatments on dental hard tissues and composite resin restorations. J Dent. 